\title{
Readability of Higher-order Thinking (HOT) Mathematical Problems in Disaster Context for Junior High School Students
}

\author{
Fahlida Harnita ${ }^{1}$ Rahmah Johar ${ }^{1, *}$ Rina S. Oktari ${ }^{2,3}$ \\ ${ }^{1}$ Department of Mathematics Education, Universitas Syiah Kuala, Indonesia \\ ${ }^{2}$ Department of Family Medicine, Universitas Syiah Kuala, Indonesia \\ ${ }^{3}$ Tsunami and Disaster Mitigation Research Center (TDMRC), Universitas Syiah Kuala, Indonesia \\ "Corresponding author. Email: rahmah.johar@unsyiah.ac.id
}

\begin{abstract}
Disaster mitigation efforts in learning mathematics need to be carried out to foster disaster awareness in students through higher-order thinking (HOT) mathematical problems in a disaster context. One effort that can be done is to design HOT math problems with disaster context. However, the problems developed have not gone through the readability test stage by students. This study aims to analyze the readability of HOT mathematical problems in a disaster context for junior high school students. This research is development research limited to the stages of one-to-one and small group only. This study resulted in 16 HOT math problems in a disaster context for junior high school students who had passed the readability test. This research is expected to provide a scientific contribution as a basis and reference for further research and the problems that have been tested for readability can be used by teachers in the teaching and learning process in the classroom.
\end{abstract}

Keywords: Higher-Order Thinking, Problem Readability, Disaster Context.

\section{INTRODUCTION}

Geographic location and population size affect an area's vulnerability to disasters [1-2]. Indonesia is one of the largest archipelagic countries in Asia and even in the world with a population of 268.1 million people [3]. Located in an area where three tectonic plates meet, namely the Indo-Australian Plate, the Eurasian Plate, and the Pacific Plate, Indonesia is one of the most seismically active areas on earth [3]. During 2019, Indonesia experienced 3.814 disaster events [4]. It can be concluded that Indonesia is a disaster-prone area.

These conditions require the community to increase awareness of disasters from an early age as a disaster mitigation effort. Government Regulation of the Republic of Indonesia Number 21 of 2008 mentions mitigation as a series of disaster risk reduction efforts. Disaster mitigation can be done physically through infrastructure development and psychologically through awareness of disaster threats. Disaster mitigation can be applied in all aspects, especially in the field of education. Education contributes to prosperity by equipping people with the knowledge and skills for problem-solving and helping to provide a sense of control and mastery in life [5].

The application of disaster mitigation in the field of education can increase disaster knowledge and change attitudes of the community, especially in schools located in disaster risk areas [6]. Efforts that can be made are to include disaster material as a compulsory subject in schools [7]. Disaster mitigation can also be applied using disaster context in learning [8], including in learning mathematics.

The implementation of mathematics learning in schools should follow the 21st-century learning mandate. 21 st-century skills refer to various skills such as learning and innovation skills consisting of critical thinking, creativity, collaboration, and communication skills [9]. These skills can be grown through Higher Order Thinking (HOT) problems.

The HOT problem is a problem used to measure highlevel skills consisting of the ability to analyse, evaluate, and create [10]. HOT problems can be enriched by integrating various contexts, including disaster contexts. The HOT math problem in disaster context is a problem 
that can measure high-level thinking skills and contains disaster problems [11]. Students' higher-order thinking skills can be measured, including through solving HOT math problems in the context of a disaster.

The results of research conducted by [12] showed that teachers did not have math problems in a disaster context and only a small number of students had read math problems in a disaster context. The research concludes that math problems with disaster contexts are still limited and need to be developed. [13] have developed a math problem in the context of a disaster, but it is only limited to one problem, even though problems with a disaster context help students to raise awareness of disasters and knowledge about disaster mitigation [14]. Thus, it can be concluded that mathematical problems in disaster contexts are still limited and need to be developed.

Previous research has attempted to develop problems with HOT characteristics and accommodate disaster contexts which resulted in 16 HOT math problems in a disaster context for junior high school students that meet theoretical validity [11]. However, the problems developed have not gone through the readability test stage by students as users. In fact, the readability test was carried out to see the understanding or readability of the problems on the research subject after the HOT math problems in disaster context were tested [15]. The higher the level of readability of the problem, the easier it is to understand. Thus, readability is a measure of whether a problem is appropriate for students in terms of the level of difficulty and ease of understanding the problem. Based on the description above, this study aims to analyse the readability of HOT math problems in a disaster context for junior high school students.

\section{METHODS}

This research is development research [16] which consists of self-evaluation, expert review, one-to-one, small group, and field test. Because this study aims to determine the readability of HOT math problems in a disaster context and is a follow-up study from [11], the researchers carried out the one-to-one and small group stages only. The one-to-one stage involves three students with high, medium, and low abilities. The small group stage involves six students with various abilities. The subjects of the study were class VIII students for the 2020/2021 academic year at one of the public junior high schools in Banda Aceh City.

In the one-to-one stage, students are asked to read and examine the problems and then give responses about the readability and clarity of the meaning of the problems. The findings obtained are used in revising prototype 1 . The results of this revision of prototype 1 are prototype 2. Next, prototype 2 is tested on students in the small group stage. Students were asked to solve prototype 2 problems. Then, the students were also asked to respond to the problems they had worked on. Based on the data from students' answers and comments on the problems on prototype 2 , the problems were revised again. The results of the revised prototype 2 are called prototype 3 which is the final prototype in this study.

Readability data about problems was obtained through open interviews and tests. The instruments in this study were open interview guide sheets, test sheets, and field notes. Interview guide sheets were used to obtain readability data through students' understanding of the problems. The test sheet contains 16 problems developed at the expert review stage consisting of problems with the context of drought, climate change, forest fires, earthquakes, volcanic eruptions, natural disasters, tsunamis, landslides, and flash floods. The questions are at levels C4 (analyse), C5 (evaluate), and C6 (create). The test sheet is used to collect readability data through students' answers. Field notes are used as support to record data that supports the readability of the problems during interviews and tests. The data analysis was carried out descriptively by analysing, describing, and summarizing the conditions of the various data collected.

\section{RESULT AND DISCUSSION}

\subsection{One-to-one}

Students are asked to read and examine the problems so that researchers can analyse student responses regarding the readability and clarity of the meaning of the problems. Based on the analysis of the results of interviews with students with high, medium, and low abilities, it was concluded that of the 16 problems developed, 11 problems were revised, namely problem 1 , problem 2 , problem 3 , problem 5 , problem 6 , problem 7 , problem 9 , problem 10, problem 11, problem 14, problem 15. The following description explains the results of student comments through interviews.

\subsubsection{Problem with the context of drought}

Problem 1 with the context of drought disaster mitigation relates to the material of number operations. This problem was developed to meet the learning objectives where students can solve problems related to arithmetic operations with integers correctly. The problems are at level $\mathrm{C} 4$ where the problems can measure the ability to analyse. Problem 1 before the revision can be seen in Figure 1 and Figure 2.

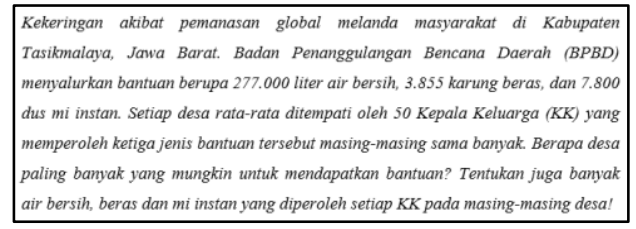

Figure 1. Prototype 1 of Problem 1 (in Bahasa) 


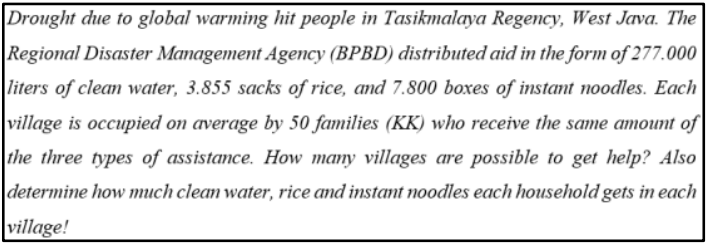

Figure 2. Prototype 1 of Problem 1 (in English)

Student comments on these problems are presented in Table 1.

Table 1. Student comments on Problem 1

\begin{tabular}{|c|c|c|}
\hline $\begin{array}{l}\text { Student } \\
\text { Ability }\end{array}$ & Comments/responses & Revision Decision \\
\hline High & $\begin{array}{l}\text { I don't understand the } \\
\text { sentence "berapa desa } \\
\text { paling banyak yang } \\
\text { mungkin untuk } \\
\text { mendapatkan } \\
\text { bantuan?". } \\
\text { ("How many villages are } \\
\text { possible to get help?") }\end{array}$ & $\begin{array}{l}\text { Replace the sentence } \\
\text { "berapa desa paling } \\
\text { banyak yang mungkin } \\
\text { untuk mendapatkan } \\
\text { bantuan?" ("How } \\
\text { many villages are at } \\
\text { most possible for } \\
\text { assistance?") } \\
\text { becomes "tentukan } \\
\text { jumlah desa paling } \\
\text { banyak yang } \\
\text { mendapat } \\
\text { bantuan!"("Determine } \\
\text { the number of } \\
\text { villages that receive } \\
\text { the most } \\
\text { assistance!".). }\end{array}$ \\
\hline Medium & $\begin{array}{l}\text { To answer this problem, } \\
\text { we need to do division. } \\
\text { Ma'am, I'm not having } \\
\text { problems with the } \\
\text { numbers. }\end{array}$ & (no revision) \\
\hline Low & $\begin{array}{l}\text { The numbers used are } \\
\text { too big, Ma'am, I also } \\
\text { don't understand } \\
\text { division, Ma'am. }\end{array}$ & (no revision) \\
\hline
\end{tabular}

Based on these comments, the revisions made to this problem can be seen in Figure 3 and Figure 4.
Kekeringan akibat pemanasan global melanda masyarakat di Kabupaten Tasikmalaya, Jawa Barat. Badan Penanggulangan Bencana Daerah (BPBD) menyalurkan bantuan berupa 277.000 liter air bersih, 3.855 karung beras, dan 7.800 dus mi instan. Setiap desa rata-rata ditempati oleh 50 Kepala Keluarga (KK) yang memperoleh ketiga jenis bantuan tersebut masing-masing sama banyak. Tentukan jumlah desa paling banyak yang mendapat bantuan! Tentukan juga banyak air bersih, beras dan mi instan yang diperoleh setiap KK pada masing-masing desa!

Figure 3. Prototype 2 of Problem 1 (in Bahasa)

Drought due to global warming hit people in Tasikmalaya Regency, West Java. The
Regional Disaster Management Agency (BPBD) distributed aid in the form of 277.000
liters of clean water, 3.855 sacks of rice, and 7.800 boxes of instant noodles. Each
village is occupied on average by 50 families (KK) who receive the same amount of
the three types of assistance. Determine the maximum mumber of villages that will
receive assistance! Also determine how much clean water, rice and instant noodles
each household gets in each village!

Figure 4. Prototype 2 of Problem 1 (in English)

\subsubsection{Problem with the context of climate change}

Problem 7 with the context of climate change relates to the material for presenting data. This problem was developed to meet the learning objectives, namely, students can interpret the data presented in the form of line diagrams correctly. This problem is at level C6 because it measures the ability to be creative. Problem 7 before the revision can be seen in Figure 5 and Figure 6 .

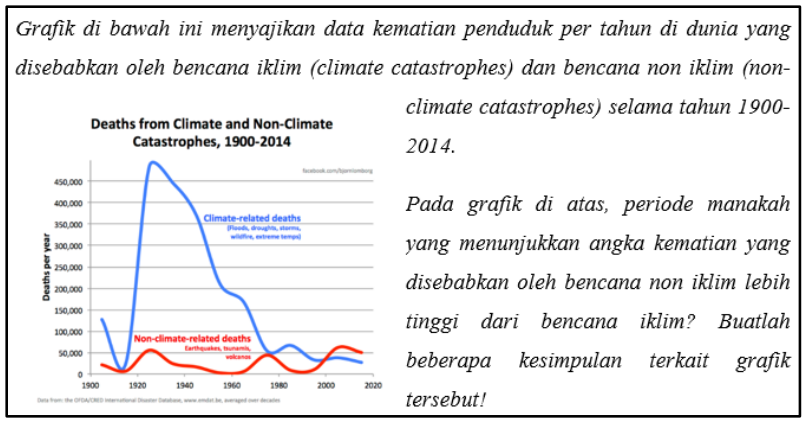

Figure 5. Prototype 1 of Problem 7 (in Bahasa)

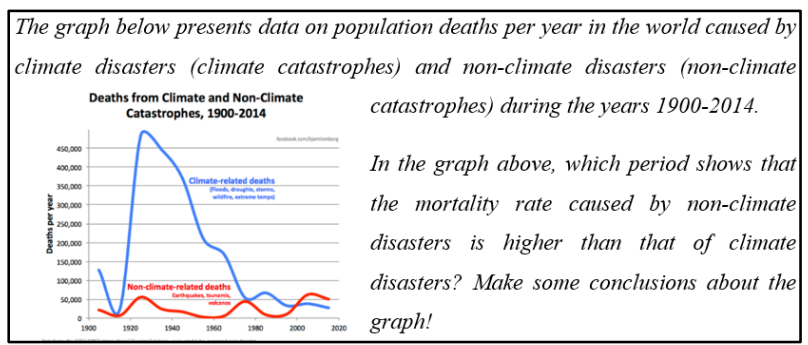

Figure 6. Prototype 1 of Problem 7 (in English)

Student comments on these problems are presented in Table 2.

Table 2. Student comments on Problem 7.

\begin{tabular}{l|l|l} 
Student & Comments/responses & Revision \\
Ability & & Decision
\end{tabular}




\begin{tabular}{|l|l|l|}
\hline High & $\begin{array}{l}\text { The language and } \\
\text { instructions are clear. }\end{array}$ & (no revision) \\
\hline Medium & $\begin{array}{l}\text { I'm a little difficult to } \\
\text { understand because the } \\
\text { explanation on the } \\
\text { graph is in English. If I }\end{array}$ & $\begin{array}{l}\text { Change } \\
\text { graphic } \\
\text { could change this insa } \\
\text { problem, I would make } \\
\text { a graphic caption in } \\
\text { Indonesian. }\end{array}$ \\
\hline Low don't know how to \\
answer this problem, \\
ma'am.
\end{tabular}

Based on these comments, the revisions made to this problem can be seen in Figure 7 and Figure 8.

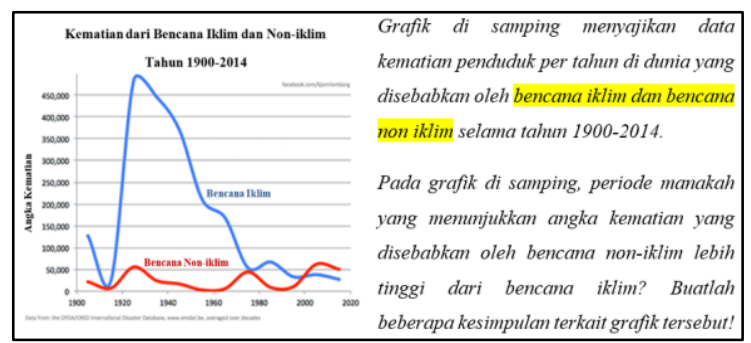

Figure 7. Prototype 2 of Problem 7 (in Bahasa)

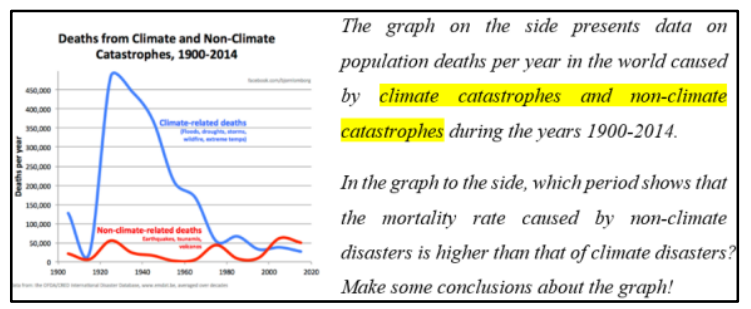

Figure 8. Prototype 2 of Problem 7 (in English)

\subsubsection{Problem with the context of forest fires}

Problem 15 with the context of forest fires relates to comparative material. This problem was developed to meet the learning objectives, namely, students can solve contextual problems related to the scale appropriately. This problem is at level $\mathrm{C} 4$ because it measures the ability to analyze. Problem 15 before the revision can be seen in Figure 9 and Figure 10.

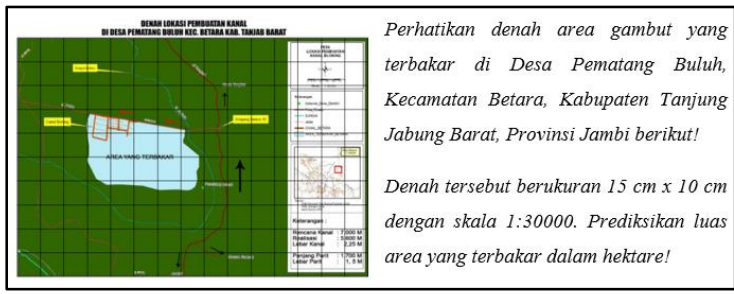

Figure 9. Prototype 1 of Problem 15 (in Bahasa)

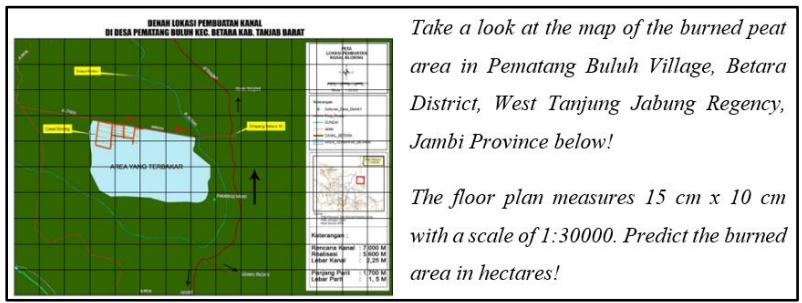

Figure 10. Prototype 1 of Problem 15 (in English)

Student comments on these problems are presented in Table 3.

Table 3. Student comments on Problem 15

\begin{tabular}{|c|c|c|}
\hline $\begin{array}{l}\text { Student } \\
\text { Ability }\end{array}$ & Comments/responses & $\begin{array}{l}\text { Revision } \\
\text { Decision }\end{array}$ \\
\hline High & $\begin{array}{l}\text { There are two different } \\
\text { information, namely in } \\
\text { the picture and the } \\
\text { problem, the } \\
\text { information in the } \\
\text { picture is confusing, } \\
\text { ma'am. }\end{array}$ & $\begin{array}{l}\text { Remove the } \\
\text { information in } \\
\text { the picture and } \\
\text { replace the } \\
\text { information in } \\
\text { the problem. }\end{array}$ \\
\hline Medium & $\begin{array}{l}\text { The problem is } \\
\text { understandable, but I'm } \\
\text { curious what kind of } \\
\text { peat soil it is, ma'am. } \\
\text { The floor plan in the } \\
\text { picture is a canal } \\
\text { construction plan. }\end{array}$ & $\begin{array}{l}\text { Removes } \\
\text { information in } \\
\text { the image. }\end{array}$ \\
\hline Low & $\begin{array}{l}\text { The problem is the area } \\
\text { where the fire occurred, } \\
\text { isn't it, ma'am. }\end{array}$ & (no revision) \\
\hline
\end{tabular}

Based on these comments, the revisions made to this problem can be seen in Figure 11 and Figure 12. 


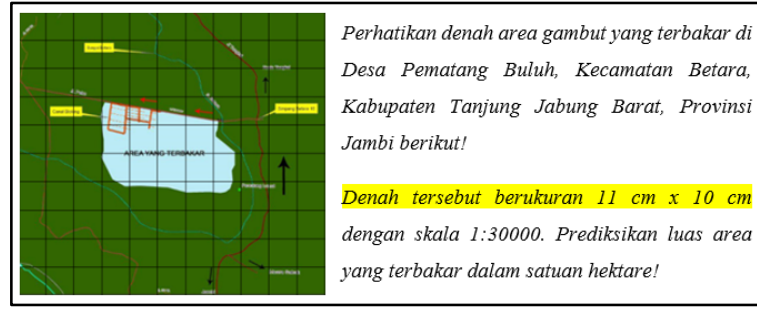

Figure 11. Prototype 2 of Problem 15 (in Bahasa)

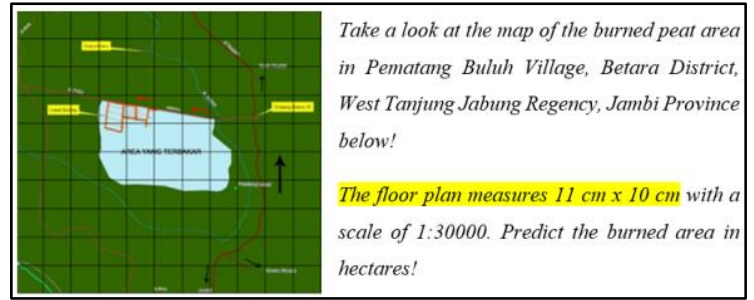

Figure 12. Prototype 2 of Problem 15 (in English)

\subsection{Small-Group}

The small group stage involves 6 different students from the previous stage. Students are asked to look at the problems and comment on the problems they have completed. The results seen are the practicality of each item for students. In general, all the problems have been understood and solved, there are only a few problems that still need to be revised because they lead to different interpretations from the actual meaning of the problems. At this stage, two problems were revised, namely problem 6 and problem 10 out of 16 developed problems. The results of students' work on the problems at the small group stage and the process of revising prototype 2 to prototype 3 are presented below.

\subsubsection{Problem with the context of an earthquake}

Problem 4 with the context of an earthquake deals with the matter of linear inequalities in one variable. This problem was developed to meet the learning objectives, namely, students can determine the limits of a variable from a problem that is known correctly. This problem is at level $\mathrm{C} 4$ because it measures the ability to analyse. Students' answers to this problem can be seen in Figure 13.

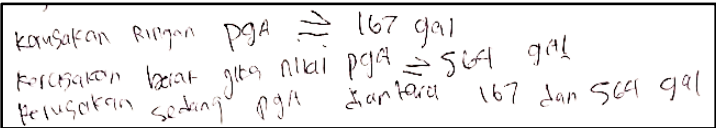

Figure 13. Student answers to problem 4 on prototype 2

Figure 13 shows that students have modelled the limits of light and heavy PGA scores correctly. Students are also able to analyse moderate PGA scores in their own sentences, but students have not converted the sentences into mathematical models. Based on the results of the interviews, students claimed to have understood the meaning of the problems so that problem 4 was not revised.

\subsubsection{Problem with the context of an erupting volcano}

Problem 6 with the context of a volcanic eruption is related to comparative material. This problem was developed to meet the learning objectives, namely that students can solve problems related to comparisons of worth correctly. This problem is at level C6 because it measures the ability to be creative. One of the students' answers to this problem can be seen in Figure 14.

$$
\begin{aligned}
V_{\text {lasi }} & =\frac{3 \mathrm{~km}}{\frac{1}{6} \mathrm{sam}}=\frac{\frac{3}{1} \mathrm{Km}}{\frac{1}{6} \mathrm{Jcm}}=\frac{3 \times 6}{1 \times 1} \text { xecepatan }=18 \mathrm{~km} / \mathrm{smm} \\
& =\frac{8 \mathrm{~km}}{27 \mathrm{~km} / \mathrm{sam}}=0,291 \mathrm{\mu m} \\
& =\frac{5 \mathrm{~km}}{18 \mathrm{~km} / \mathrm{mam}}=0,27
\end{aligned}
$$

Figure 14. Student answers to problem 6 on prototype 2

The results of student work show that the student has been right in calculating the time it takes for Siti and the lava flow to get to a safe point, but the student has not been able to compare the time of the two and make conclusions from their results. Based on the results of interviews, this is because students feel that this problem does not make sense because the time difference between Siti and the lava flow at the safe point is very small, so if it is adjusted in reality, Siti will definitely not survive. This condition is the reason for the revision of problem 6 , which is to increase the time difference between Siti and the lava flow to make it more logical and acceptable.

\subsubsection{Problem with the context of natural disasters}

Problem 8 with the context of natural disasters relates to the material for presenting data. This problem was developed to meet the learning objectives, namely that students can interpret the data presented in the form of a pie chart correctly. This problem is at level C4 because it measures the ability to analyse. One of the students' answers to this problem can be seen in Figure 15. 


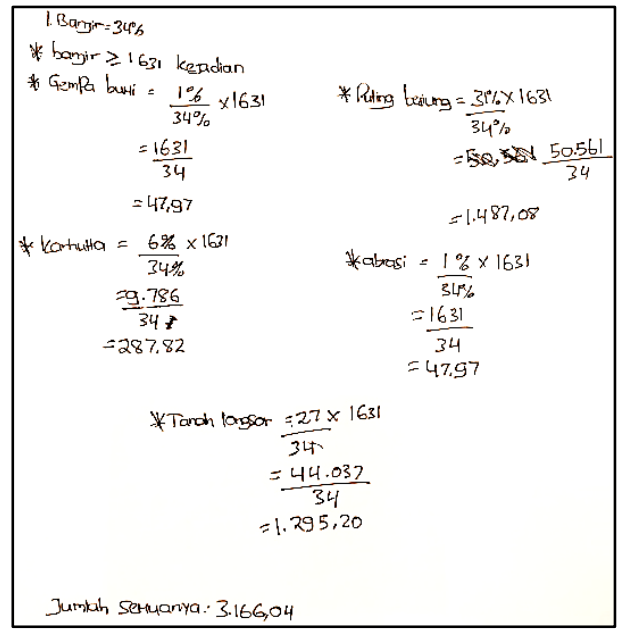

Figure 15. Student answers to problem 8 on prototype 2

Figure 15 shows that the student has completed the problem with the right steps, but the student is wrong in making conclusions. The answer obtained by the student is wrong because the student does not include the number of flood events in the calculation. Based on the results of the interviews, students claimed to have understood the meaning of the problems so that problem 8 was not revised.

\subsubsection{Problem with tsunami context}

Problem 9 with the context of the tsunami relates to the material of flat shapes. This problem was developed to meet the learning objectives, namely that students can solve contextual problems related to the area of rectangles and triangles correctly. This problem is at level C6 because it measures the ability to be creative. One of the students' answers to this problem can be seen in Figure 16.

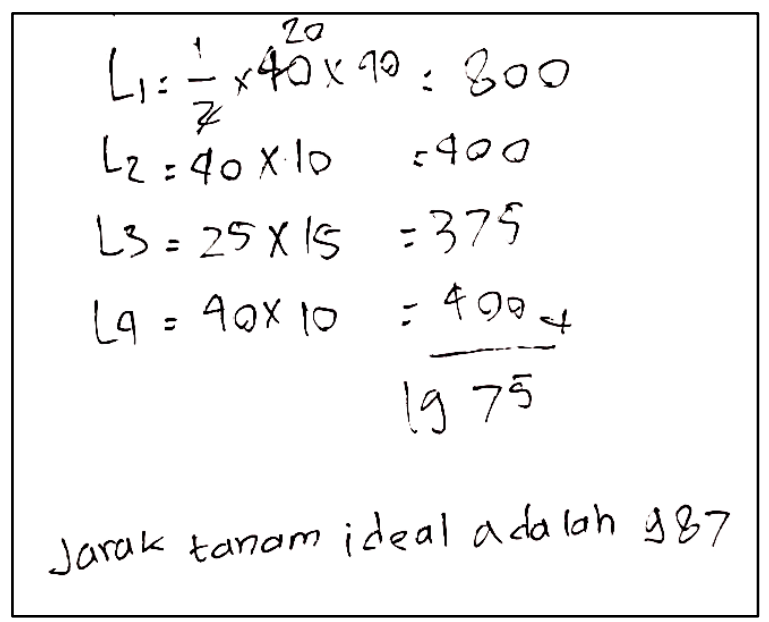

Figure 16. Student answers to problem 9 on prototype 2

The result of student work shows that the student is correct in calculating the area of land to be planted with mangroves, but the student has not been able to predict the number of mangrove trunks that can be planted.
Based on the results of the interviews, students claimed to have understood the meaning of the problems, so that problem 9 was not revised.

\subsubsection{Problem with landslide context}

Problem 10 with the context of landslides is related to the number pattern material. This problem was developed to meet the learning objectives, namely, students can solve contextual problems related to number patterns correctly. This problem is at level $\mathrm{C} 4$ because it measures the ability to analyze. One of the students' answers to this problem can be seen in Figure 17.

$$
\begin{aligned}
& \begin{array}{l}
\text { Dik: tinggi ternah pdasar sampai teraserng paling atas: } 156 \mathrm{M} \\
\text { Ada } 13 \text { tinglazan }
\end{array} \\
& \text { Dit : tingleat ys dibutuhtean uth he } 241 \mathrm{M} \\
& \text { Jawab: Jarah Antar tingleatan }=\text { jarah toal: jumlah tinglatan } \\
& \therefore 156: 13=12 \mathrm{~m} / \text { tinglactan } \\
& \text { Dik: T:241 M } \\
& \text { D.t: Tingleatonnya }=241 / \text { sarale anter } t \text { : ingleatan } \\
& =241 / 12 \\
& =20,0033334
\end{aligned}
$$

Figure 17. Student answers to problem 10 on prototype 2

Figure 17 shows that the student is correct in estimating the number of levels that can be made if the terrace height becomes $241 \mathrm{~m}$, but the student does not use the concept of number patterns in answering. According to students, problems can be easily solved by division operations because each level has the same height. Because the problems were not optimal in achieving the learning objectives, a revision was made to problem 10. The revision was to replace the initial tribal values that were not the same as different values so that solving the problem required students to use arithmetic number patterns.

\subsubsection{Problem with flood context}

Problem 13 with flood context relates to the material of a two-variable linear equation system. This problem was developed to meet the learning objectives, namely, students can solve contextual problems of a two-variable linear equation system with the correct elimination method. This problem is at level $\mathrm{C} 4$ because it measures the ability to analyse. One of the students' answers to this problem can be seen in Figure 18. 


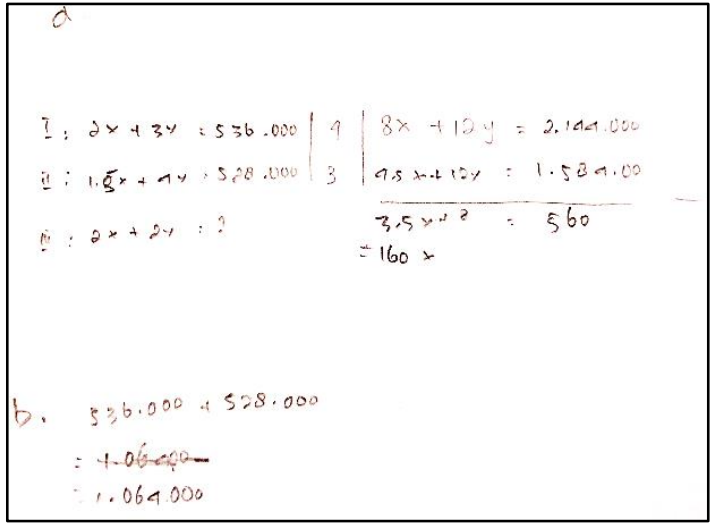

Figure 18. Student answers to problem 13 on prototype

The results of student work show that the student has been able to model the given problem but have not been able to solve the system of linear equations of the two variables. Based on the results of the interviews, students already understood the meaning of the problems, but students had difficulties with the material. Because there was no ambiguity in the problem, problem 13 was not revised.

This study was conducted to test the readability of HOT problems in a disaster context through the stages of one-to-one and small groups. The designed problems underwent various revisions considering the comments and students' answers to the problems. In the one-to-one stage, there were 11 of the 16 problems that were revised, while at the small group stage, there were two of the 16 problems that were revised. The revisions made were changing words or terms that were more communicative, changing the information on problems that made more sense, and adjusting the demands of the problems to the learning objectives.

Substitution of words or terms that are difficult to understand by junior high school students need to be revised, such as the word 'consistent' in problem 13, 'assumption', and 'linear' in problem 6. The term 'consistent' has not been used in the editorial problems in the junior high school textbook; the word 'assumption' has been used in textbooks for class VII, VIII, and IX, but students do not know its meaning, while the meaning of the term 'linear' is not explained [17]. In line with that, previous researchers also revised some terms or sentences that were difficult for students to understand [18]. The information provided on the problems must be closely related to students' daily lives [19] so that mathematics can be well received by students. Based on this fact, it is hoped that the teacher will get used to clarifying new terms that appear on the problems so that the vocabulary of the students also increases.

Giving problems in the form of real problems is needed so that students can be able to transform these problems in the context of mathematics [20]. The disaster context that is integrated into the HOT math problems has a good impact on students. Students get useful new information and can broaden their horizons, such as the history of disasters in Indonesia, types of disasters, disaster mitigation efforts, locations of disasters, etc. Students also gain a lot of new vocabulary from reading problems that they did not know before, such as peat soil, mangrove plants, terraces, reservoirs, etc.

Most students feel that the problems they get are quite difficult and have never been encountered before, but students feel challenged to solve these problems. Students are interested in solving problems that they think are important in everyday life. Seen from the two stages of research, students gave a positive response to the problems provided. Students feel happy if they can solve the problem because they think the given problem is important in everyday life. This is in line with the results of research by [21], students who work on math problems like PISA in the context of Islamic values get new insights and knowledge that motivate them to do good.

HOT math problems in disaster contexts are important to be developed. HOT math problems in disaster contexts require thinking skills in finding solutions to disaster problems [22]. That way, students' understanding of disasters can increase and disaster mitigation knowledge will be embedded in students [23] In addition, students are happier in learning because they can solve problems that are closer to the world of students [24].

This research is a follow-up study from the development stages [16] namely one to one and small group. This research is limited in terms of assessing the readability of the problems. The next researcher is expected to be able to continue the development stage, namely the field test and test the validity of the problems empirically.

\section{CONCLUSION}

This study resulted in 16 HOT math problems in disaster context for junior high school students who had been tested for readability through one-to-one and small group stages. Based on these two stages, 11 problems were revised at the one-to-one stage and two problems were revised at the small group stage. Revisions were made in the form of changing terms that are easier for students to understand, adjusting the information on the problems so that they can be well received by students, and adjusting the demands of the problems to the learning objectives.

\section{AUTHORS' CONTRIBUTIONS}

All authors conceived and designed this study. All authors contributed to the process of revising the 
manuscript, and at the end all authors have approved the final version of this manuscript.

\section{REFERENCES}

[1] N. Britton, I. Walker, Hazard Analysis and Risk Assessment for Local Government, Unit 2 course notes for the Disaster Management for Local Government program, University of New England 1991.

[2] J.M. Nigg, The Social Impacts of Physical Process: How Do We Manage What We Can't Control?. Disaster Research Center Preliminary Paper 245 (1996).

URL: https://udspace.udel.edu/bitstream/handle/19716/64 $6 /$ ? sequence $=1$

[3] BPSI. Statistik Indonesia dalam Infografis 2020 (Badan Pusat Statistik), 2020. URL: https://www.bps.go.id/publication/2020/04/27/0a44 c683a28ef50c7586adee/statistik-indonesia-dalaminfografis-2020.html

[4] S. Data, 11 Januari 2021 Kejadian Bencana tahun 2019, BPNB, $2019 . \quad$ URL: https://bnpb.go.id/infografis/kejadian-bencanatahun-2019

[5] S. Bowen, Language barriers in access to health care, Health Canada., 2001.

[6] M. Desfandi, Urgensi Kurikulum Pendidikan Kebencanaan Berbasis Kearifan Lokal di Indonesia, SOSIO DIDAKTIKA: Social Science Education Journal 1(2) (2014) 191-198. DOI: $\underline{10.15408 / \mathrm{sd} . v 1 \mathrm{i} 2.1261}$

[7] I. Hasanah, S. Wahyuni, Pengembangan Modul Mitigasi Bencana berbasis Potensi Lokal yang terintegrasi dalam pelajaran IPA di SMP, Jurnal Pembelajaran Fisika 5(3) (2016) 226-34. URL: https://jurnal.unej.ac.id/index.php/JPF/article/view/ 4064

[8] A. Rusilowati, A. Binadja, S.E.S. Mulyani, Mitigasi Bencana Alam Berbasis Pembelajaran Bervisi Science Environment Technology And Society, Jurnal Pendidikan Fisika Indonesia 8(1) (2012) 5160. DOI: https://doi.org/10.15294/jpfi.v8i1.1994

[9] M. Binkley, O. Erstad, J. Herman, S. Raizen, M. Ripley, M. Runmble, Partnership for 21st century skills, Springer, Dordrecht, 2012, pp: 17-66.

[10] L.W. Anderson, et al, A Taxonomy for Learning, Teaching, and Assessing; A Revision of Bloom's Taxonomy of Education Objectives, New York: Addison Wesley Lonman Inc., 2001.
[11] F. Harnita, R. Johar, M. Hasbi, S. Sulastri, Validitas Soal Higher-Order Thinking Skill Matematika Berkonteks kebencanaan untuk Siswa Sekolah Menengah Pertama, Jurnal Elemen 7(1) (2021) 113. DOI : $10.29408 /$ jel.v7i1.2460

[12] N. Nuzulidar R. Johar, S. Sulastri, Teacher's and Student's Needs for Mathematical Problems in Disaster Context, Infinity Journal 8(2) (2019) 239246 (2019). DOI: https://doi.org/10.22460/infinity.v8i2.p239-246

[13] M. Khalid, D.H.P.H. Ali, Inculcating Tsunami Awareness in a Mathematics Lesson: Improving Students' Collaborative Problem Solving via Lesson Study, Southeast Asian Mathematics Education Journal 6(1) 19-31 (2016). DOI: https://doi.org/10.46517/seamej.v6i1.37

[14] S. Fatimah, R. Johar, C.M. Zubainur, Students' Logical Mathematical Intelligence in Completing Mathematical Problems with Natural Disaster Context, Journal of Physics: Conference Series 1470(1) (2020) 012022. URL: https://iopscience.iop.org/article/10.1088/17426596/1470/1/012022/meta

[15] P.D. Kristanto, P.G.F. Setiawan, Kristanto, Priantoro Dwi, and Paula Glady Frandani Setiawan. "Pengembangan Soal HOTS (Higher Order Thinking Skills) Terkait Dengan Konteks Pedesaan", PRISMA, Prosiding Seminar Nasional Matematika, 3 (2020) 370-376. URL: https://journal.unnes.ac.id/sju/index.php/prisma/arti cle/view/37616

[16] M. Tessmer, Planning and conducting formative evaluations: Improving the quality of education and training (London: Kogan Page), Routledge, 1993.

[17] A.R As'ari, M. Tohir, E. Valentino, Z. Imron, I. Taufiq. Matematika SMP/MTs Kelas VIII Semester I Kurikulum 2013 Edisi Revisi 2017, Kemdikbud, 2017.

[18] M.N. Prabawati, T. Herman, T. Turmudi, Pengembangan Lembar Kerja Siswa Berbasis Masalah dengan Strategi Heuristic untuk Meningkatkan Kemampuan Literasi Matematis Mosharafa: Jurnal Pendidikan Matematika 8(1) (2019) 37-48. DOI: https://doi.org/10.31980/mosharafa.v8i1.383

[19] I.F. Ulya, R. Irawati, M. Maulana, Peningkatan kemampuan koneksi matematis dan motivasi belajar siswa menggunakan pendekatan kontekstual, Jurnal Pena Ilmiah 1(1) (2016) 121-130. DOI: https://doi.org/10.23819/pi.v1i1.2940. 
[20] H. Khusna, S. Ulfah, Kemampuan Pemodelan Matematis dalam Menyelesaikan Soal Matematika Kontekstual, Mosharafa: Jurnal Pendidikan Matematika 1(1) (2021) 153-64. DOI: https://doi.org/10.23819/pi.v1i1.2940

[21] M. Lutfianto, A.F. Sari, Respon siswa terhadap soal matematika mirip PISA dengan konteks berintegrasi nilai islam, Jurnal Elemen 3(2) (2017) 108-17. URL:

https://core.ac.uk/download/pdf/206315009.pdf

[22] M. Hasyim, F.K. Andreina, Analisis high order thinking skill (HOT) siswa dalam menyelesaikan soal open ended matematika FIBONACCI: Jurnal Pendidikan Matematika dan Matematika 5(1) (2019) 55-64. DOI: https://doi.org/10.24853/fbc.5.1.55-64

[23] B. Hayudityas, Pentingnya penerapan pendidikan mitigasi bencana di sekolah untuk mengetahui kesiapsiagaan peserta didik, Jurnal Edukasi Nonformal 1(2) (2020) 96. URL: https://ummaspul.ejournal.id/JENFOL/article/view/407

[24] A.D. Purwanti, Penerapan pendekatan kontekstual untuk meningkatkan minat belajar siswa pada pembelajaran IPA di sekolah dasar", Jurnal Ilmiah Guru "COPE" 16(2) 1-6. DOI: http://dx.doi.org/10.21831/jig\%20cope.v16i2.3957 